\title{
都市撤退（リバース・スプロール）に関する計測手法の開発とその適用*
}

\section{Development and Application of the New Index to Diagnose Reverse Sprawl*}

\author{
谷口守**・松中亮治***・妹尾一慶**** \\ By Mamoru TANIGUCHI ** • Ryoji MATSUNAKA*** • Kazunori SEO ****
}

\section{1. 背景・目的}

高度経済成長期以降の急激な人口増加やモータリゼー ションの進展などに伴い, 都市形態は変容し, 都市の郊 外化が急速に進行した. 急速な郊外化は様々な面で都市 における弊害を生み, 特に, 郊外化の進行に対応しきれ ないまま無秩序な開発が進行した郊外部の市街地では, 現在に至るまでスプロール現象と呼ばれる都市問題を蓄 積させている.

しかし, 人口減少社会へと移行しつつある近年, 需要 や開発志向の低下などに伴い, 地区内の建築物が消失し ていく都市撤退が新たな現象として明らかとなってきて いる. もし, これらの現象が無秩序に進行するならば, 開発時に発生したスプロール以上の都市問題をもたらす 可能性がある. そのことから, 今後, 都市撤退の進行を 地区レベルで把握できる評価手法が必要と考えられる.

しかし, 都市撤退に着目した先行研究は, リバース・ スプロールの定義を行った実態分析 ${ }^{1}$ や居住地立地誘導 検討のために撤退・再集結地区特定法を構築したもの 2 などわずかしかなく, 都市撤退の進行そのものを評価す る指標は未だ考案されていない. 一方, スプロールの定 量化についてはそのコストに着目したもの ${ }^{3)}$, メッシュ ごとの建筑物数ランクからスプロール進行の概要をモデ ル化したもの), 街路へのアクセス性を変数として市街 化モデルを構築したもの ${ }^{5}$, 地区内の道路率や人口密度 からスプロール地区を分類したもの市など多くの既存研 究が存在する. ただし，指標化を念頭においた研究では 街路のみに着目したり,メッシュなど地区単位で一意的 に決まる指標が中心で, 建築物単位で生じる土地利用変 化の特徵を十分に反映できる指標は存在しなかった.

また，本指標の概念である建筑物同士の位置的関係を 取り扱った先行研究には, 建築物の独立性を周囲の建築 物との距離から定義したもの ${ }^{7}$, 建築物間距離から建築 物の近接性を定量化したもの ${ }^{8)}$, 空地を隣接距離と隣接

\footnotetext{
*キーワーズ: 地区計画, 土地利用, 市街地整備 都市撤退

** 正会員, 工博, 岡山大学環境学研究科

*** 正会員, 博 (工), 岡山大学環境学研究科

*****正会員, 姫路市役所

T7700-8530 岡山市津島中3-1-1 TEL • FAX 086-251-8921
}

関係から分類するモデルを構筑したもの9などがある. ただし，建築物の周囲に設定する一定領域との重複関係 から隣接を定義し，その隣接状況から都市撤退の非効率 性評価を可能とした本研究とは主旨が異なる.

これらを踏まえ, 本研究では, 地区内で発生する都市 撤退の非効率性を建筑物同士の隣接状况からミクロな視 点で評価できる指標を考案するとともに, 開発に関して も同様の指標を考案する. また, 市街地形成時の整備手 法が異なる郊外部の市街地に評価指標を適用し, 開発及 び都市撤退の非効率性を市街地のタイプごとに定量分析 する.

\section{2. 本研究の特徵と分析対象地区}

(1) 本研究の特徵

本研究では, まず, 同地区における2時点の住宅地図 を照合し, 前時点と比較して建筑物が新たに建設されて いる変化を「開発」, 前時点と比較して建築物が消失し ている変化を「都市撤退」として抽出する. さらに，住 宅地図上に建築物単位で抽出した開発及ひ都市撤退の分 布状況・進行状況に着目し，それらの非効率性を評価で きる指標を考案する. ただし，開発の進行に伴う非効率 性を「スプロール度」として捉え, 都市撤退の進行に伴 う非効率性をスプロールと表裏の関係にある点に着眼し， 「リバース・スプロール度」として捉え議論を進める.

本論文では，スプロール度を評価するスプロール指 標として視点が異なる4つの指標, リバース・スプロー ル度を評価するリバース・スプロール指標として視点が 異なる2つの指標を考案する. また，考案したそれぞれ の評価指標を市街地形成時の整備手法が異なる郊外部の 3地区に適用することで，市街地のタイプ別に開発及び 都市撤退の非効率性を様々な視点から比較分析する.

(2) 分析対象地区について

本研究では, 地方中心都市の岡山市において, 全国都 市パーソントリップ調査の対象としてランダムに選ばれ た 30 住区のうち, 最寄り駅までの距離条件等から判断 して同程度の開発ポテンシャルを持つ郊外部の 3 地区を 対象とする. ただし，選定した 3 地区は市街地形成時の 
整備手法がそれぞれ異なり，計画性にそしいスプロール 市街地である岡山市赤田, 土地区画整理事業が行われた 市街地である岡山市平田, 一時期に開発が進められた一 体的開発市街地である岡山市富士見町の 3 地区である.

(表-1, 図-1)

また，いずれの地区も4時点の住宅地図を使用してい るが，開発及ひ都市撤退を抽出する際の分析データとし て, 土地利用変化を分析した変化期間, 各変化期間に該 当する地区内の開発建築物及ひ撤退建築物の総数を表一 2に示す.

\section{3. 評価指標に関連する概念}

（1）ロットの位置付け

本研究では, 一単位の用途で活用される最小の敷地 として, 形状を多角形に近似したロットを定義し, ロッ 卜同士の隣接状況を評価する. 想定するロットは建築物 に付随する外構 ${ }^{(1)}$ 含むものであるが，着目する1つの 建築物に1つのロットが対応するように設定するため, 着目する建築物の数とそれに該当するロットの数は一致 する. また，本分析では，建築物を伴わない農地や空き 地，駐車場などにも着目するが，それらにおいても最小 の敷地単位で同様のロットを想定して取り扱う.

（2）隣接条件の定義

本研究で定義したロットのうち, 評価指標に適用し ていくロットを ‘抽出ロット’とし，隣接状況を判断す る上で, 隣接の対象となり得る周囲のロットを“対象口

表-1 分析対象地区の概要 ${ }^{10)}$

\begin{tabular}{|c|c|c|c|c|c|c|c|}
\hline \multirow{2}{*}{ 対象地区 } & \multicolumn{3}{|c|}{ 人口(人) } & \multirow{2}{*}{$\begin{array}{l}\text { 面皘 } \\
\text { (ha) }\end{array}$} & \multirow{2}{*}{$\begin{array}{c}\text { 市の中心地 } \\
\text { までの距離 } \\
(\mathrm{km})\end{array}$} & \multirow{2}{*}{$\begin{array}{l}\text { 最寄山の } \\
\text { 鉄道卧 }\end{array}$} & \multirow{2}{*}{$\begin{array}{c}\text { 最㟢りの } \\
\text { までの距暗 } \\
(\mathrm{km})\end{array}$} \\
\hline & 1995年 & 2000年 & 2005年 & & & & \\
\hline $\begin{array}{c}\text { 岡山市 } \\
\text { 赤田 }\end{array}$ & 1944 & 2017 & 1976 & 29.1 & 4.3 & $\begin{array}{c}\text { JR山龧本線 } \\
\text { 高岛限 }\end{array}$ & 0.6 \\
\hline $\begin{array}{c}\text { 岡山市 } \\
\text { 平田 }\end{array}$ & 2236 & 2463 & 2881 & $※ 45.2$ & 4.7 & 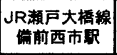 & 1.2 \\
\hline $\begin{array}{c}\text { 周山市 } \\
\text { 副士見町 }\end{array}$ & 622 & 579 & 581 & 7.4 & 8.6 & $\begin{array}{l}\text { JR赤稳楾 } \\
\text { 大多篗駅 }\end{array}$ & 0.9 \\
\hline
\end{tabular}

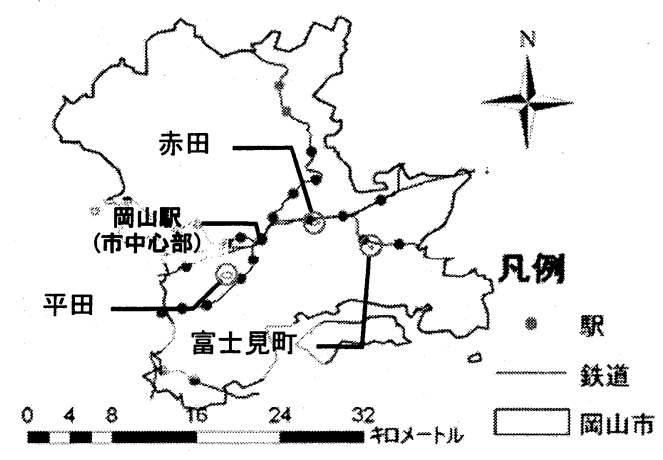

図-1 分析対象地区の位置
ット’と表現する. 抽出ロットに着目したとき, 各辺上 の点における外向きの法線の集合のうち, 辺からの距離 が4m(閾值)以内(建築基淮法における道路幅員を参考)で ある長方形のエリアを各辺における ‘隣接領域” と定義 し，抽出ロットの各辺における外向きの方向を ‘領域方 向” と定義する. (図一2) 定義上, 隣接領域及び領域方 向は多角形に近似した抽出ロットの辺数と一致する.

また, 抽出ロットの隣接領域のうち, 周囲の対象ロッ トとの重複部分が一部でも存在するもの(図一2では, 対 象ロット(1)のみが該当)を隣接条件が成立している隣接 領域と見なし，それに該当する領域方向数(図一2では， 上方向のみで1)を抽出ロットにおける ‘隣接数” と定 義する. そのため, 抽出ロットにおける隣接数は隣接条 件を満たす領域方向数であり, 抽出ロットとの隣接が成 立している対象ロットの数とは必ずしも一致しない.

\section{（3）制約条件の設定}

本研究では, 上記の隣接条件とは別に, 該当する領 域方向に対して隣接の成立自体を考慮しない制約条件を 設ける. 例えば, 建築基淮法で定義される幅員 $4 \mathrm{~m}$ 以上の 街路が抽出ロットの辺に接している場合(図一2では, 抽 出ロットの左方向が該当), その領域方向に対しては,

隣接領域に対象ロットが重複し得ないことより, 隣接そ のものが想定され得ない：このような隣接の成立自体を 制約する物理的・公共的な条件を制約条件として位置付 ける.（具体的には，幅員4m以上の街路，物理的に開発 不能な土地，公園，地区の境界を指す)この制約条件に より, 対象ロットとの隣接が存在し得ないと判断できる

\section{表ー2 住宅地図による分析データ}

\begin{tabular}{|c|c|c|c|c|c|c|c|c|}
\hline \multirow{2}{*}{ 対象地区 } & \multicolumn{4}{|c|}{ 麦化期明 } & \multicolumn{4}{|c|}{ 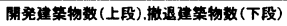 } \\
\hline & 変化 I & 麦化 II & 麦化III & 全変化 & 变化 I & 妻化 II & 轰化回 & 全麦化 \\
\hline \multirow{2}{*}{$\begin{array}{l}\text { 岡山市 } \\
\text { 示田 }\end{array}$} & \multirow{2}{*}{$\begin{array}{c}1976 \text { 年 } \\
\text { 1994年 }\end{array}$} & \multirow{2}{*}{$\begin{array}{c}\text { 1994年 } \\
\text { 1999年 }\end{array}$} & \multirow{2}{*}{\begin{tabular}{|c} 
1999年 \\
2005年
\end{tabular}} & \multirow{2}{*}{$\begin{array}{c}1976 \text { 年 } \\
\text { 2005年 }\end{array}$} & 233 & 57 & 34 & 312 \\
\hline & & & & & 7 & 8 & 23 & 34 \\
\hline \multirow{2}{*}{$\begin{array}{l}\text { 岡山市 } \\
\text { 平田 }\end{array}$} & \multirow{2}{*}{$\begin{array}{c}\text { 1978年 } \\
\text { 1994年 }\end{array}$} & \multirow{2}{*}{$\begin{array}{c}\text { 1994年 } \\
\text { 1999年 }\end{array}$} & \multirow{2}{*}{\begin{tabular}{|c} 
1999年 \\
2005年
\end{tabular}} & \multirow{2}{*}{$\begin{array}{c}\text { 1978年 } \\
\text { 2005年 }\end{array}$} & 286 & 75 & 80 & 432 \\
\hline & & & & & 10 & 22 & 24 & 50 \\
\hline \multirow{2}{*}{$\begin{array}{c}\text { 周山市 } \\
\text { 畐士見町 }\end{array}$} & \multirow{2}{*}{$\begin{array}{l}\text { 1977年 } \\
\text { 1994年 }\end{array}$} & \multirow{2}{*}{$\begin{array}{l}\text { 1994年 } \\
\text { 1999年 }\end{array}$} & \multirow{2}{*}{$\begin{array}{l}\text { 1999年 } \\
\text { 2005年 }\end{array}$} & \multirow{2}{*}{$\begin{array}{l}\text { 1977年 } \\
\text { 2005年 }\end{array}$} & 37 & 1 & 3 & 41 \\
\hline & & & & & 2 & 1 & 4 & 5 \\
\hline
\end{tabular}

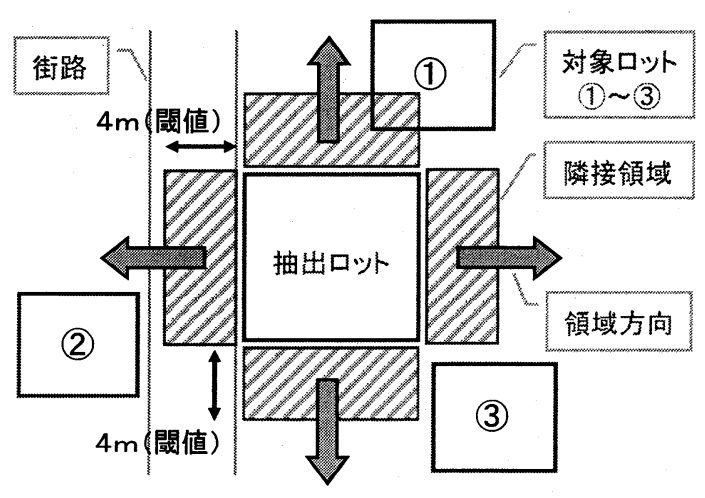

図一2 隣接に関連する概念図 
方向を差し引いた領域方向数(図一2では, 左方向を除く 3方向)を ‘隣接可能数” と定義する. ゆえに, 隣接可能 数とは可能であると考えられる隣接数の最大值と一致し, 抽出ロットにおける対象ロットとの隣接数はいかなる場 合も隣㢺可能数以下となる.

\section{4. スプロールに関する評価指標の考案}

スプロールに関する評価指標として, 散布度, 乱雑 度, 脆弱度, 不調和度という 4 種類のスプロール指標 ( prawl Index : SI)を考案し, 以下に示す. いずれの評価 指標も2時点間の比較で抽出される地区内の開発建築物 (抽出ロット)に着目しており, それら各々の隣㢺状況を 評価指標に適用していくことで地区全体としてのスプロ

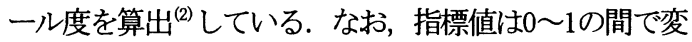
動し，1に近いほどスプロール度は高くなる。

（1）スプロール指標(散布度) : $S I_{s d}$ スプロール指標(散布度)では，スプロールをまとま りの無い単独開発の進行として捉え，地区内における開 発の進行パターンを散らばり度合いの観点から評価して いる. 本指標では, 個々の開発建築物が互いにまとまっ ているほどスプロール度が低く，逆に個々の開発建築物 が散らばっているほどスプロール度が高くなる. よって, 本指標は比較する2時点間での開発がどの程度, 計画性 に欠けたばらついたものであるかを地区単位で把握する 際に有効と言える. (図一-3)以下に, スプロール指標(散 布度)の評価式を示す。

$$
S I_{s d}=1-\frac{\sum_{d=1} a_{d}{ }^{d b}}{\sum_{d=1} A_{d}}
$$

$a_{d}{ }^{d b}$ : 個々の開発建築物のロット[抽出ロット]におけ

る，他の開発建築物のロット[対象ロット]との 隣接数

$A_{d}$ : 個々の開発建築物のロット[抽出ロット]におけ

る隣接可能数

（2）スプロール指標(乱雑度)：S $I_{d d}$

スプロール指標(乱雑度)では，スプロールを市街地 拡散に寄与する無秩序な開発として捉え，地区内におけ る閒発の進行エリアを建筑物密度の観点から評価してい る. 本指標においては，建筑物密度が高い(周囲を囲む 建築物が多い)場所(市街地内部など)での開発ではスプ ロール度が低く, 逆に建築物密度が低い(周囲を囲む建 筑物が少ない)場所(市街地端部など)での開発ではスプ ロール度が高くなる. よって, 本指標は比較する2 時点
間での開発がどの程度, 地区内の無秩序なエリアで進行 しているかを把握する際に有効と言える. (図一4)以下 に，スプロール指標(乱雑度)の評価式を示す.

$$
S I_{d d}=\frac{\sum_{d=1} a_{d}{ }^{n b}}{\sum_{d=1} A_{d}}
$$

$a_{d}{ }^{n b}$ : 個々の開発建築物のロット[抽出ロット]におけ

る, 建築物を伴わない(農地, 空き地, 単独の敷 地を有する駐車場など)ロット[対象ロット]との 隣接数

$A_{d} \quad$ : 個々の開発建築物のロット[抽出ロット]におけ る隣接可能数

（3）スプロール指標(脆弱度)：S $I_{f d}$ スプロール指標(脆弱)では, スプロールをインフ ラ整備の不十分な土地における開発として捉え，インフ ラ整備の一つである幅員4m以上の街路との隣接状況(開 発建築物が幅員 $4 \mathrm{~m}$ 以上の街路と接し，その街路と直接出 入りが可能か否か)から, 緊急車両等の進入を考慮した 際の防災面での脆弱性を評価している. 本指標において は, 幅員4m以上の街路と接する開発の割合が高いほどス プロール度が低く, 逆に幅員4m以上の街路と接する開発 の割合が低いほどスプロール度が高くなる. よって, 本 指標は比較する2時点間での開発がどの程度, 防災面の 脆弱な環境下で進行しているかを把握する際に有効と言 える. (図一5)以下に, スプロール指標(脆弱度)の評価 式を示す，なお，脆弱度のみ，評価指標の性質上，該当 するロット数の割合により算出される.

$$
S I_{f d}=1-\frac{l_{d}}{L_{d}}
$$

$l_{d}:$ 幅員 $4 \mathrm{~m}$ 以上の街路と接する開発建築物のロット数 $L_{d} \quad$ : 開発建築物のロット総数

（4）スプロール指標(不調和度) : $S I_{i d}$ スプロール指標(不調和度)では，スプロールを地区 レベルでの一貫性が欠如した開発として捉え, 開発に伴 う計画性の低さをロット分割の不均一性から評価してい る. 本指標においては, 周囲の建築物と均一なロット形 状を有する開発の割合が高いほど不調和度が低く，逆に 周囲の建築物之不均一なロット形状を有する開発の割合 が高いほど不調和度が高くなる. よって, 本指標は比較 する2時点間での開発がどの程度, 無秩序な敷地形状で 
進行しているかを把握する際に有効と言える.（図一6) 以下に, スプロール指標(不調和度)の評価式を示す。

$$
S I_{i d}=1-\frac{\sum_{d=1} a_{d}{ }^{s b b}}{\sum_{d=1} a_{d}{ }^{e b}}
$$

$a_{d}{ }^{s b b}:$ 個々の開発建築物のロット[抽出ロット]におけ

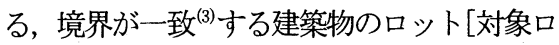
ット]との隣接数

$a_{d}{ }^{e d}$ : 個々の開発建築物のロット[抽出ロット]におけ

る，建築物を伴う(開発建築物または既存建築

物)ロット[対象ロット]との隣接数

上記で考案した評価指標の適用例として，基盤整備 (地区内の街路配置)のレベルを変化させた簡便な格子モ デル(図一7)を用い，その算出結果 ${ }^{(4)}$ を表一3に示す。そ の結果, 3種類のモデルの指標値は異なる傾向を示して いると言え，特に，基盤整備が最も充実したパターン3 においてスプロール度が低くなる結果が得られた。

\section{5. リバース・スプロールに関する評価指標の考案}

リバース・スプロールに関する評価指標として, 散 布度, 乱雑度という 2 種類のリバース・スプロール指標 (Reverse Sprawl Index : RSI) 考案し, 以下に示す. いずれの評価指標も2時点間の比較で抽出される地区内 の撤退建築物(抽出ロット)に着目しており, それら各々 の隣接状況から地区全体としてのリバース・スプロール 度を算出 ${ }^{(5)}$ している. なお，指標值は0〜1の間で変動し， 1に近いほどリバース・スプロール度は高くなる.

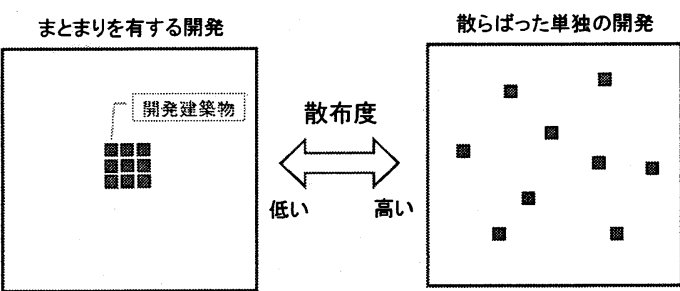

図ー3 スプロール指標(散布度)の概念図

街路(幅 $4 \mathrm{~m}$ 以上)に接する開発

街路(幅4m以上)に接していない開発
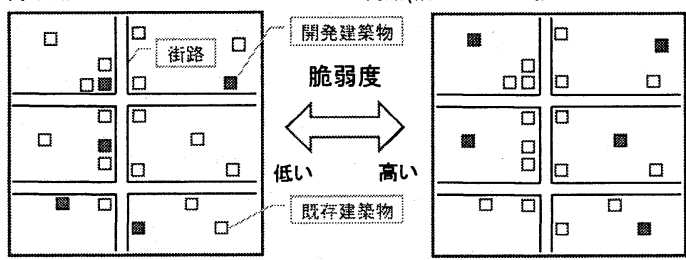

図－5 スプロール指標(脆弱度)の概念図
（1）リバース・スプロール指標(散布度) : RS $I_{s d}$

リバース・スプロール指標(散布度)では，リバース

・スプロールをまとまりの無い単独撤退の進行として捉 え，地区内における撤退の進行パターンを散らばり度合 いの観点から評価している. 本指標においては，個々の 撤退建築物が互いにまとまっているほどリバース・スプ ロール度が低く，逆に個々の撤退建築物が散らばってい るほどリバース・スプロール度が高くなる. よって, 本 指標は比較する2時点間での都市撤退がどの程度, 計画 性に欠けたばらついたものであるかを地区単位で把握す る際に有効と言える. (図一8)以下に, リバース・スプ ロール指標(散布度)の評価式を示す。

$$
R S I_{s d}=1-\frac{\sum_{r=1} a_{r}^{r b}}{\sum_{r=1} A_{r}}
$$

$a_{r}^{r b}$ : 個々の撤退建築物のロット[抽出ロット]にお ける，他の撒退建築物のロット[対象ロット] との隣接数

$A_{r}$ : 個々の撤退建築物のロット[抽出ロット]にお ける隣接可能数

（2）リバース・スプロール指標(乱雑度)：RS $I_{d d}$ リバース・スプロール指標(乱雑度)では，リバース ・スプロールを市街地密度の低下に寄与する非効率な都 市撤退として捉え，地区内における都市撤退の進行エリ アを建築物密度の観点から評価している. 本指標におい ては，建築物密度が低い(周囲を囲む建築物が少ない)場 所(市街地端部など)での都市撤退ではリバース・スプロ

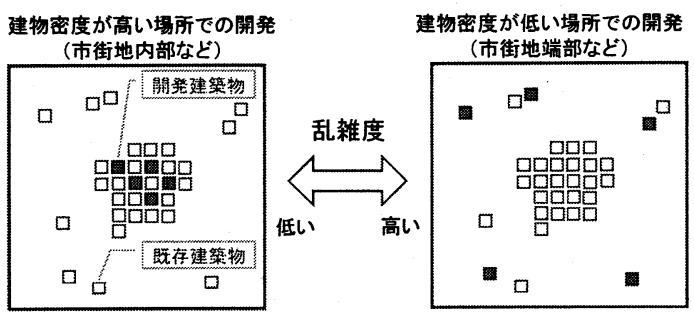

図ー4 スプロール指標(乱雑度)の概念図

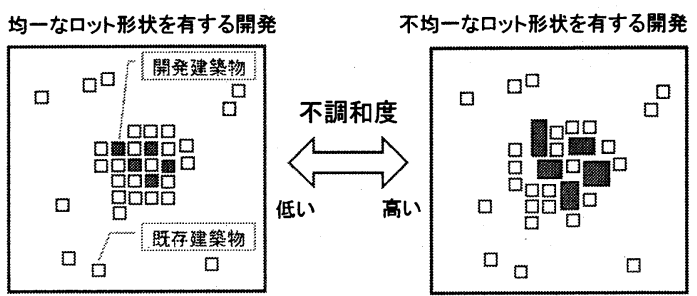

図一6 スプロール指標(不調和度)の概念図 

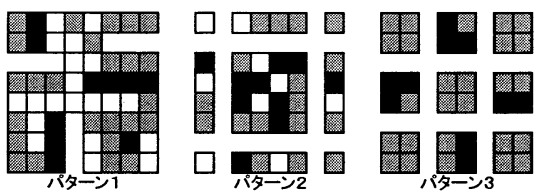

図一7格子モデル(スプロール度)

表ー3＼cjkstart格子モデルにおけるスプロール度

\begin{tabular}{|c|c|c|c|}
\hline スプロール指標 & パターン1 & パターン2 & パターン3 \\
\hline 散布度 & 0.636 & 0.692 & 0.400 \\
\hline 乱雑度 & 0.333 & 0.346 & 0 \\
\hline 脆弱度 & 0.600 & 0.200 & 0 \\
\hline
\end{tabular}

一ル度が低く，逆に建築物密度が高い(周囲を囲む建築 物が多い)場所(市街地内部など)での都市撤退ではリバ 一ス・スプロール度が高くなる. よって, 本指標は比較 する2時点間での都市撤退がどの程度, 地区内の無秩序 なエリアで進行しているかを把握する際に有効と言える. (図一9)特に, 乱雑度の低い都市撤退は地区レベルで見 ると市街地のコンパクト化に寄与する撤退として評価で き，また乱雑度の高い都市撤退は市街地の空洞化に寄与 する撤退として評価できる．以下に，リバース・スプロ 一ル指標(乱雑度)の評価式を示す。

$$
R S I_{d d}=\frac{\sum_{r=1} a_{r}^{e b}}{\sum_{r=1} A_{r}}
$$

$a_{r}^{e b}$ : 個々の撤退建築物のロット[抽出ロット]にお

ける，建築物を伴う(開発建築物または既存建 築物) ロット[対象ロット]との隣接数

$A_{r}$ : 個々の撤退建築物のロット[抽出ロット]にお ける隣接可能数

上記で考案した評価指標の適用例として，基盤整備 (地区内の街路配置)のレベルを変化させた簡便な格子モ デル(図ー10)を用い，その算出結果を表一4に示す。 そ の結果, 基般整備のレベルが高いパターン2の方がパタ ーン1と比ベてリバース・スプロール度が低くなる結果 が得られた。

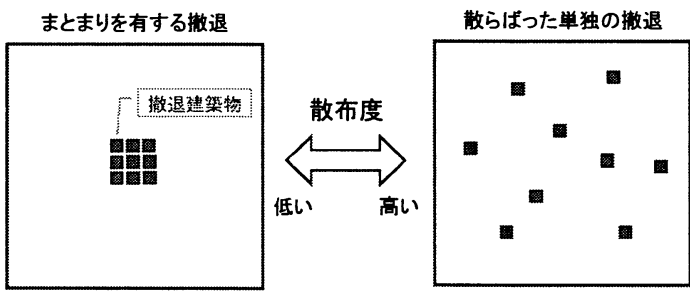

図ー8 リバース・スプロール指標(散布度)の概念図

\section{6. 評価指標の適用}

本章では，市街地形成時の整備手法が異なる3地区に 対し上記で考案したスプロール指標及びリバース・スプ ロール指標を適用し，分析結果を提示する．以下に，適 用例としてスプロール市街地である岡山市赤田の全変化 (図一11)，土地区画整理事業が行われた市街地である岡 山市平田の全変化(図-12) 及び一体的開発市街地であ る岡山市富士見町の全変化(図ー13)を示すとともに，各 地区の変化期間ごとに算出したスプロール度(図一14)・ リバース・スプロール度 (図-15) 及び変化 I 〜IIIにおけ るスプロール度の平均值(表一5)・リバース・スプロー ル度の平均值 $($ 表一6)を示す。

（1）スプロール指標を用いた分析結果

本分析では，変化期間ごと(表一2で提示)に抽出した 全ての開発建築物を対象に，ロット単位で個々の隣接状 況を評価し，4種類のスプロール指標に適用していく. なお，岡山市富士見町の変化II及び変化而の分析におい ては, 開発建築物数自体が少ないことより分析から除外 している. 本研究で考案したスプロール指標を分析対象 地区である3地区に適用すると，以下のことが明らかと なる.

1）スプロール市街地である岡山市赤田では，いずれの 指標も比較的高い值で推移しており，効率性を欠いた開 発が地区内で進行していると言える. まず，散布度から は地区内の開発が比較的散らばったものであること，乱 雑度からは建築物が外部(自然的土地が有するある一定 のエリア)方向に拡散する開発であることが読み取れる. また, 脆弱度や不調和度では, 他の2地区と比較しても 高い值となっており，街路網やロット分割の面での非効 率性が顕著となっている.

2）土地区画整理事業が行われた市街地である岡山市平 田では，必ずしも指標が低い值とはなっておらず，散布 度及ひ乱雑度は高い值となっている. 地区内における開 発の立地パターンのみに着目寸ると，無秩序な開発パタ 一ンを呈していると言える. ただし，地区内の基盤整備 が進んでいることから，脆弱度及ひ不調和度は低い值を 示しており，開発パターンにおける非効率性を緩和して いる.

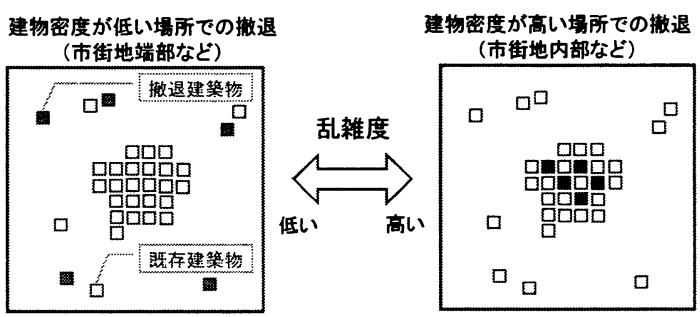

図ー9 リバース・スプロール指標(乱雑度)の概念図 


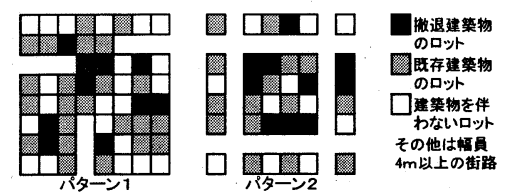

図-10 格子モデル(リバース・スプロール度

表一4 格子モデルにおけるリバース・スプロール度

\begin{tabular}{|c|c|c|}
\hline $\begin{array}{c}\text { Jバース・ } \\
\text { スプロール指標 }\end{array}$ & パターン1 & パターン2 \\
\hline 散布度 & 0.765 & 0.583 \\
\hline 乱雑度 & 0.471 & 0.375 \\
\hline
\end{tabular}

3）一体的開発市街地である岡山市富士見町では，スプ ロール指標が全体的に低い值を示している.これは，一 体的開発が終了すると，それ以降はスプロール的な開発 が抑えられることを意味している.

（2）リバース・スプロール指標を用いた分析結果

本分析では, 変化期間ごと (表一2で提示) に抽出した 全ての撤退建築物を対象に, ロット単位で個々の隣接状 況を評価し，2種類のリバース・スプロール指標に適用 していく. なお，岡山市富士見町の分析においては，撤

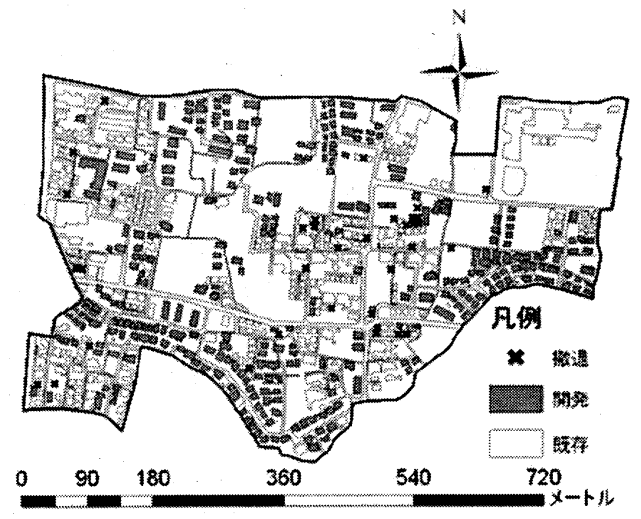

図ー11岡山市赤田の全変化(1976年 2005年)

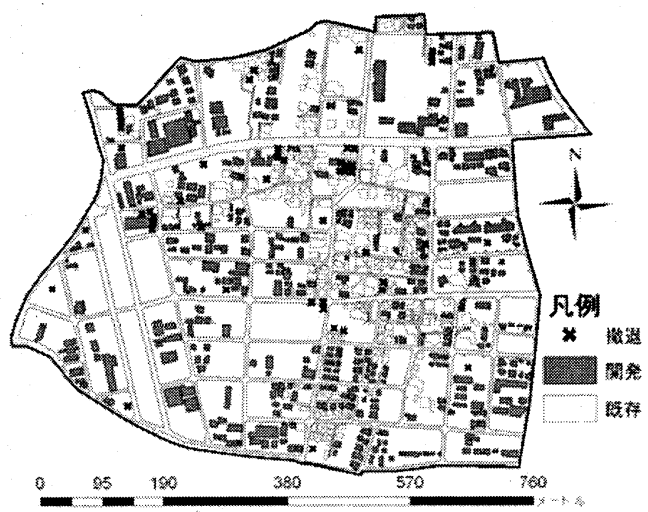

図ー12 岡山市平田の全変化(1978年〜2005年)
退建築物数自体が少ないことより分析から除外している. 本研究で考案したリバース・スプロール指標を岡山市赤 田及び岡山市平田に適用すると，以下のことが明らかと なる.

1）スプロール市街地である岡山市赤田では，散布度及 び乱雑度が共に高い值となっており, 非効率な都市撤退 が生じていると言える. 散布度に着目すると, 指標値が 1でないことから必ずしも全ての都市撤退が単独で生じ ているわけではないが, 地区全体で評価すると散らばっ た都市撤退であることが読み取れる. また, 乱雑度に着 目すると, 地区内の都市撤退が比較的建築物で囲まれた 場所で生じており, 歯抜け状に生じる非効率な都市撤退 であることが読み取れる. 特に，スプロール市街地にお いては開発が撒退建築物を覆うように進行するケースも 見られるため, より一層乱雑度が高くなっていると考え られる.

2）土地区画整理事業が行われた市街地である岡山市平 田では, 散布度及び乱雑度が共にスプロール市街地と比 較して低い值となっており, ある程度の秩序を内在した 都市撤退であると言える. 散布度に着目すると, スプロ 一ル市街地と比べて単独撤退の割合が低く, 土地再編の 可能性を秘めたまとまりを有する都市撤退であることが 読み取れる. また, 乱雑度に着目すると比較的, 自然的 土地に接する場所で建築物が撤退しており, 市街地整備 の流れにおいて建物更新という形で都市撤退が生じたこ とが理解できる.

\section{7. 結論と考察}

評価指標の考案及び上記の定量分析で得られた結果 を整理すると以下のようになる.

1）本研究では，任意の 2 時点間における土地利用変化の 非効率性に着目し, 時間的に同次元でありながら異なる 視点で評価可能な数種類の指標を開発, 都市撤退の両側 面から考案した.

2）既に，いずれの地区においても都市撤退は確認でき るが, 本指標の適用により, それらの発生割合及び進行 に伴う非効率性は市街地形成時における整備手法の違い

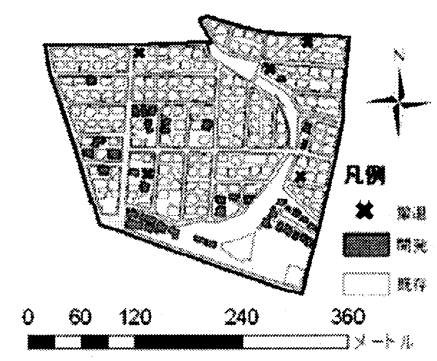

図ー13岡山市富士見町の全変化(1977年 2005年) 


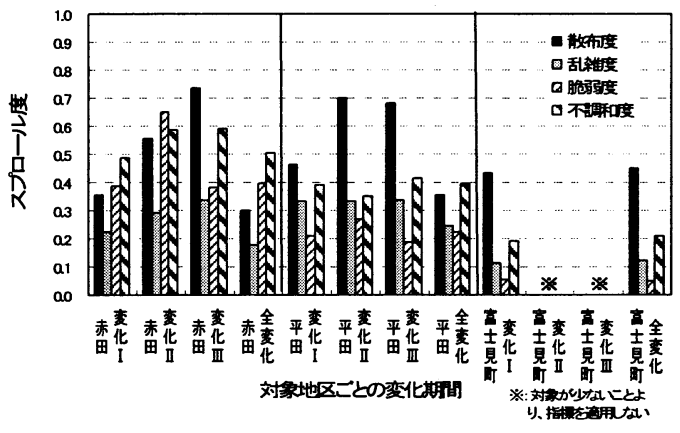

図一14 各地区におけるスプロール度

$$
\text { 表ー5 スプロール度の平均値(変化 I 〜 III) }
$$

\begin{tabular}{|c|c|c|c|c|}
\hline 対象地区 & i ) $S I$ (散布度) & ii ) $S I$ (乱雓度) & iii) $S I$ (脆弱度 & iv) $S I$ (不調和度 \\
\hline $\begin{array}{c}\begin{array}{c}\text { 岡山市赤田 } \\
\text { (開発) }\end{array}\end{array}$ & 0.547 & 0.283 & 0.473 & 0.555 \\
\hline 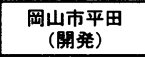 & 0.615 & 0.333 & 0.221 & 0.385 \\
\hline $\begin{array}{l}\text { 岡山市富士見町 } \\
\text { (開発) } \\
\text { ※は除く }\end{array}$ & 0.432 & 0.114 & 0.054 & 0.190 \\
\hline
\end{tabular}

によりそれぞれ異なることが定量的に分析できた.

3）非計画的に形成されたスプロール型地区においては, 開発に伴うスプロール度が高いとともに, 都市撤退に伴 うリバース・スプロール度も高いことが明確に示された. 特に, 当地区は非効率な開発と非効率な都市撤退が同時 に進行しており, 二重の非効率性を内在した土地利用変 化がなされている.

4）土地区画整理事業が行われた市街地では, 開発・都 市撤退共に，ある一定の非効率性を内在していると言え る. しかし，スプロール型地区と比べてその程度は小さ く, 市街地更新としてのある程度の秩序が確認できる.

5）高度成長期に一体的に開発された市街地では, 市街 地形成後に追随的な開発が進行しにくく,また, 進行し た開発に着目しても基盤整備の存在により, 地区内の秩 序は維持されている. 一方, 都市撤退においても, 現段 階においてその発生割合は低く，非効率な都市撤退が顕 在化していないことが示された.

6）対象地区におけるスプロール指標の適用により，市 街地のタイプに即したある程度妥当な結果が得られた. 併せて，スプロールとは裹返しの現象を同様の概念で評 価したリバース・スプロール指標の妥当性もある程度提 示できたと言える.

\section{8. おわりに}

本研究では, 開発及ひ都市撤退の進行形態を非効率 性という観点から評価できる指標群を考案するとともに, 市街地形成時の整備手法がそれぞれ異なる3地区への適 用を行った. 今回提案したスプロール指標, 及びリバー ス・スプロール指標は簡便なものではあるが，市街地形 成時の整備手法により都市撤退の非効率性が異なること

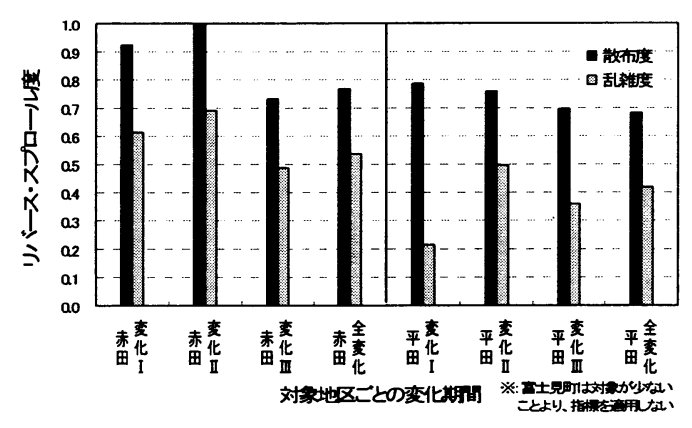

図一15 各地区におけるリパース・スプロール度

表一6 リバース・スプロール度の平均値(変化 I 〜 III)

\begin{tabular}{|c|c|c|}
\hline 対象地区 & $v) R S I$ (散布度) & $\mathrm{vi}) R S I$ (乱雑度) \\
\hline $\begin{array}{c}\text { 岡山市赤田 } \\
\text { (都市撤退) }\end{array}$ & 0.884 & 0.598 \\
\hline $\begin{array}{c}\text { 岡山市平田 } \\
\text { (都市撤退) }\end{array}$ & 0.746 & 0.356 \\
\hline
\end{tabular}

が明確に示された. 特に, スプロール市街地ほど撤退時 のリバース・スプロール度が高くなることが示され，ス プロール市街地は二重に非効率であるという問題を客観 的に提示した点は, 本研究の成果と言える. 上記のよう に，スプロールとリバース・スプロールにはある程度の 因果関係が見られ, その理由の一つには, 街路網や区画 割などの基盤整備の条件が双方の非効率性に影響してい ることが挙げられる. そのため, 地区内の基盤環境が改 善されない限り, 開発時の非効率性はある一定のレベル で都市撤退時に引き継がれるものと考えられる.

本研究で考案した評価指標の指標值のみで地区を判 断することには注意が必要であるが，様々な視点から捉 えた本指標を複合的に活用することにより，地区レベル での土地利用変化を定量的に把握することがある程度可 能となる. 今後の課題としては, 指標の安定性を複数の 地区で確認するとともに, リバース・スプロールを地区 レベルでマネジメントする仕組みを構筑する中で, 本指 標を活用していくことが考えられる.

補注 :

（1）住宅の敷地内で住居の周りに作られる塀，生垣，庭, 車庫など.

(2)スプロール指標におけるミ式は地区内で抽出した開 発建築物の隣接数または隣接可能数を個々に足し合わせ るものであり, 結果として, 全ての開発建築物の隣接状 況を反映させた地区単位で唯一に決まるスプロール度を 算出している.

(3)境界の一致とは, 同程度の幅員を持つ対象ロットが1 つの領域方向に対してただ1つ隣接し，かつロットの境 界を互いが過不足無く共有しているものと定義する. 例 として, 図一16の格子モデルを示す. 図ー16において, 
抽出ロットに対する対象ロット(1)の隣接は共有している 辺に過不足が生じているため境界が一致しているとは見 なさないが，対象ロット(2)の隣㢺は共有している辺に過 不足が無いため境界が一致していると見なす，なお，対 象ロット(3)隣接そのものが成立していない.

(4)均一な格子で形成される図一-3の格子モデルでは, 条 件により不調和度がいずれも0となるため, 評価対象か ら除外する.

(5) リバース・スプロール度の算出では抽出ロットが撤 退建築物となるものの, それ以外はスプロール度の算出 方法(補注(2)) と同様の概念である.

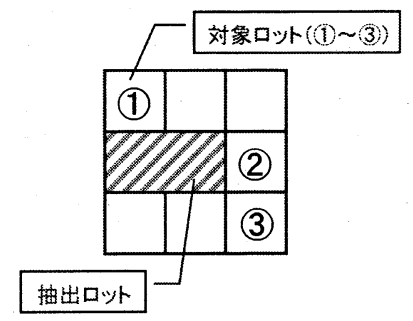

図ー16 境界の一致を示す格子モデル

参考文献

1）氏原岳人・谷口守・松中亮治 : 市街地特性に着目し た都市撤退(リバース・スプロール)の実態分析，都市計 画論文集, No. 41-3, pp. 977-982, 2006.

2）加知範康 - 加藤博和 - 林良嗣 - 森杉雅史 : 余命指標 を用いた生活環境質 (QOL) 評価と市街地拡大抑制策検討 への適用，土木学会論文集D, Vol. 62，No. 4, pp. 558-57

3, 2006.
3）黒川洸・谷口守・橋本大和・石田東生 : スプロール 市街地の整備コストに関する一考察，一先行的都市基盤 整備のコスト節减効果に関する検討一, 都市計画論文集, No. 30, pp. 121-126, 1995.

4）塚口博司 : スプロール地区における街路網計画に関 する一考察, 都市計画論文集, No. 26, pp. 235-240，19 91.

5）三谷哲雄・山中英生 : スプロール市街地における集 散街路の市街地形成効果に関する一分析, 都市計画論文 集, No. 27，pp. 205-210， 1992

6）大久保紀明 : 大都市周辺自治体における市街地整備 の効果とその課題, 一千葉県野田市における地区類型と 整備実績の考案から一, 都市計画論文集, No. 30, pp. 13 3-138, 1995.

7) 斉藤千尋 : 配置構成による建物の独立性 一浦安市市 街地を事例とした近接する建物の数, 距離, 規模の分析 一, 都市計画論文集, №. 34, pp. 649-654, 1999.

8）市古太郎・権昌希 : 既成市街地における建築物の 「近接性」の定量化に関する研究一世田谷区太子堂地 区を対象に一, 都市計画論文集，No. 37，pp.7-12， 2002. 9）市古太郎：法線走查法による建物隣接空地の定量化, 一空地の直和分解モデルとその実装一, 都市計画論文集, No. 39-3, pp. 679-684, 2004.

10）岡山市役所 : 岡山市の統計情報(HP), http://www. c it. okayama. okayama. jp/soumu/toukei/index. htm, 20 05. 12閲覧

\section{都市撤退（リバース・スプロール）に関する計測手法の開発とその適用*}

$$
\text { 谷口守 } * * \cdot \text { 松中亮治 } * * * \cdot \text { 妹尾一慶**** }
$$

本研究は，近年着目され始めた新たな現象の一つである都市撤退と従来からの現象であるスプロールに着目し， それらの非効率性を地区レベルで評価できる指標を考案したものである. その際, 従来の指標で用いられる建築物 率や道路率などよりもさらに変動が激しい個々の建筑物の変化に着眼し, 建筑物単位における土地利用変化の評価 を行った. また, 本研究で考案した指標を市街地形成時の整備手法が異なる3地区に適用することで, 市街地の夕 イプ別に都市撤退とスプロールの実態を分析した. その結果，市街地形成時における整備手法の違いが撤退時にお ける非効率性の度合いに影響していることが定量的に示された。

\section{Development and Application of the New Index to Diagnose Reverse Sprawl*}

By Mamoru TANIGUCHI **-Ryoji MATSUNAKA ***-Kazunori SEO ****

The purpose of this study is to suggest indexes to evaluate the pattern of urban retreat and development in the district. To analyze features of urban retreat and urban sprawl, indexes were applied on three different types of residential zones. Results showed, that features of urban retreat are different in different types of residential zones. In particular, it is clarified that urban retreat goes disorderly in a these there residential zone types. 